\title{
A Theoretical Investigation of the Structural, Spectroscopic and Optical Properties of Adenine
}

\author{
M. Alauddin ${ }^{1}$, M. M. Islam ${ }^{2}$, M. K. Hasan ${ }^{1}$, T. Bredow ${ }^{2}$ and M. A. Aziz ${ }^{1}$ * \\ ${ }^{1}$ Department of Chemistry, Dhaka University, Dhaka-1000, Bangladesh \\ ${ }^{2}$ Mulliken Center for Theoretical Chemistry, Institut für Physikalische und Theoretische Chemie, Universität Bonn, \\ Beringstraße 4-6, D-53115 Bonn, Germany
}

(Received : 3 September 2015; Accepted: 12 January 2016)

\begin{abstract}
The structural, spectroscopic (IR, NMR and UV-Vis) and optical properties of adenine (6-aminopurine, $\mathrm{C}_{5} \mathrm{H}_{5} \mathrm{~N}_{5}$ ) are investigated theoretically using HF/DFT hybrid approach B3LYP. The calculated results are compared with available experimental data. The optimized bond distances and bond angles are converged within $\pm 0.01 \AA$ and $\pm 0.8^{\circ}$ with respect to the experimental values. The investigation of ${ }^{1} \mathrm{H}$ NMR chemical shift spectra of the aromatic C-H protons shows that the maximum deviation of the calculated chemical shift is $\sim 0.53$ ppm compared to the experimental data. The calculated vibrational spectra analysis shows four distinct IR active mode of vibrations which are assigned as scissoring vibration of $-\mathrm{NH}_{2}$, symmetric stretching vibration of $-\mathrm{NH}_{2}$, free $-\mathrm{NH}$ vibration and anti-symmetric stretching vibration of $-\mathrm{NH}_{2}$, respectively. The electronic and optical properties are calculated by Time Dependent Density Functional Theory (TD-DFT) approach. A reasonable agreement is obtained for the calculated optical absorption energy with the experimental value.
\end{abstract}

Keywords: Adenine, TD-DFT, IR, NMR, Electronic properties, Optical absorption

\section{Introduction}

It is well known that adenine is one of the four nucleic acid bases (adenine, guanine, cytosine and thymine) that constitutes the building blocks of life. Adenine encodes the genetic information of all organisms in deoxyribonucleic acid (DNA) and ribonucleic acid (RNA) ${ }^{1-3}$ It helps stabilize the nucleic acid portion of these molecules. Additionally, adenine is found in adenosine triphosphate (ATP), a molecule that carries the energy needed for work in cells. Adenine also occurs as a component of a number of coenzymes, such as coenzyme I (nicotinamide adenine dinucleotide $\left(\mathrm{NAD}^{+}\right)$or diphosphopyridine nucleotide $\left(\mathrm{DPN}^{+}\right)$) and coenzyme II (nicotinamide adenine dinucleotide phosphate $\left(\mathrm{NADP}^{+}\right.$) or triphosphopyridine nucleotide $\left(\mathrm{TPN}^{+}\right)$). These coenzymes are often involved in oxidation-reduction processes in biological reactions together with the appropriated enzyme. These nucleobases absorb UV light strongly and act as a primary chromophores of DNA. ${ }^{4-6}$ Photostability of DNA bases is the essential criteria for the preservation of genetic information of DNA bases. As nucleobases absorb UV light strongly, therefore the knowledge of the electronic properties and excited state lifetimes are of paramount importance for understanding the UV radiation induced DNA damage. ${ }^{7-12}$ Numerous experimental and theoretical studies on DNA and DNA bases have been performed to understand structural, electronic properties and excited state lifetimes. ${ }^{13-16}$ All the calculations have been focused on the ground state to the higher electronic singlet and triplet states of the neutral molecules.

In this paper, we have performed a theoretical investigation of structural, spectroscopic, electronic and optical properties of adenine with HF-DFT hybrid approach and compared with the available experimental data. The optical properties have been calculated at the excited states using TD-DFT method.

\section{Computational Details}

The total quantum chemical calculations have been performed using hybrid approach $\mathrm{B}^{2} \mathrm{LYP}^{17}$ as implemented in the quantum chemistry package G09. ${ }^{18}$ We have used 6$311+\mathrm{G}(\mathrm{d}, \mathrm{p})$ basis set in order to calculate the structure, IR, ${ }^{1} \mathrm{H}$ NMR and UV-Vis spectra of adenine in the ground state at the B3LYP level of theory. The optimized structure of adenine in the ground state was verified by calculating vibrational frequencies to confirm that there were no imaginary frequencies. Excited state calculations have been done by TD-DFT method employing B3LYP functional and $6-311+G(d, P)$ basis set to study electronic and optical properties of adenine and we have calculated six excited states of adenine.

\section{Results and Discussion}

\section{Molecular geometry and thermodynamics parameters}

The most optimized DFT geometry by B3LYP of adenine is shown in Fig. 1 with leveling. For optimizing minimum energy structure of adenine, first we have done intrinsic reaction coordinate (IRC) calculation with $\mathrm{HF} / 6-31 \mathrm{G}$ and have taken minimum energy structure and reoptimized using DFT/B3LYP/6-311+G(d,p) level of theory.

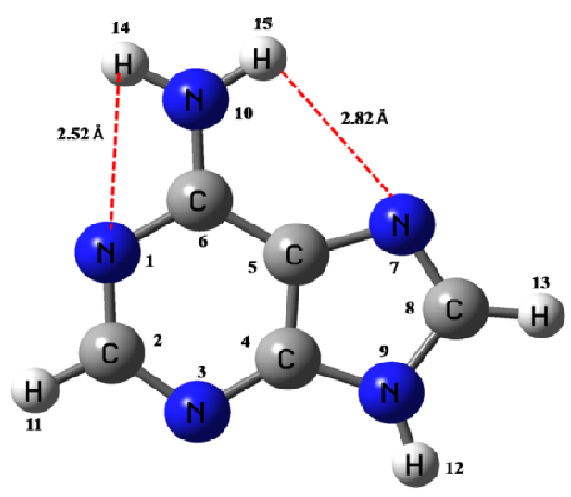

Fig. 1. Optimized structure of adenine 
The final geometry corresponds to true energy minima as revealed by the lack of imaginary frequencies in the vibrational mode calculation. Due to the lone pair of electron on the nitrogen atom in the amino group of adenine, amino group exist as bent shape. However, the optimized structure of adenine is planer which is due to the delocalization of electrons through the whole molecule. The optimized bond distances and bond angles are compared with available experimental data in Table 1.

It is observed that the bond distances converged within $\pm 0.01 \AA$ and the largest deviation of bond angle is $0.8^{\circ}$ with respect to the experimental values. ${ }^{19}$

Table 1. Comparison of calculated bond lengths $(\AA)$ and bond angles $\left(^{\circ}\right)$ with available experimental data.

\begin{tabular}{|c|c|c|c|}
\hline & & Calc. & Expt. \\
\hline \multicolumn{4}{|l|}{ Bond Length $(\AA)$} \\
\hline & $\mathrm{N}(1)-\mathrm{C}(2)$ & 1.341 & 1.338 \\
\hline & $\mathrm{C}(2)-\mathrm{N}(3)$ & 1.334 & 1.332 \\
\hline & $\mathrm{N}(3)-\mathrm{C}(4)$ & 1.340 & 1.342 \\
\hline & $C(4)-C(5)$ & 1.397 & 1.382 \\
\hline & $C(5)-C(6)$ & 1.410 & 1.409 \\
\hline & $\mathrm{C}(6)-\mathrm{N}(1)$ & 1.348 & 1.349 \\
\hline & $\mathrm{C}(4)-\mathrm{N}(9)$ & 1.373 & 1.376 \\
\hline & $\mathrm{C}(5)-\mathrm{N}(7)$ & 1.385 & 1.385 \\
\hline & $\mathrm{N}(7)-\mathrm{C}(8)$ & 1.312 & 1.312 \\
\hline & $\mathrm{C}(8)-\mathrm{N}(9)$ & 1.374 & 1.367 \\
\hline & $\mathrm{C}(6)-\mathrm{N}(10)$ & 1.348 & 1.337 \\
\hline \multicolumn{4}{|l|}{ Bond Angle $\left(^{\circ}\right)$} \\
\hline & $\mathrm{N}(1)-\mathrm{C}(2)-\mathrm{N}(3)$ & 128.5 & 129.0 \\
\hline & $\mathrm{C}(2)-\mathrm{N}(3)-\mathrm{C}(4)$ & 111.6 & 110.8 \\
\hline & $\mathrm{N}(3)-\mathrm{C}(4)-\mathrm{C}(5)$ & 126.3 & 126.9 \\
\hline & $\mathrm{C}(4)-\mathrm{C}(5)-\mathrm{C}(6)$ & 116.4 & 116.9 \\
\hline & $\mathrm{C}(5)-\mathrm{C}(6)-\mathrm{N}(1)$ & 118.3 & 117.6 \\
\hline & $\mathrm{C}(6)-\mathrm{N}(1)-\mathrm{C}(2)$ & 118.7 & 118.8 \\
\hline & $\mathrm{C}(5)-\mathrm{C}(4)-\mathrm{N}(9)$ & 104.8 & 105.7 \\
\hline & $\mathrm{N}(1)-\mathrm{C}(6)-\mathrm{N}(10)$ & 119.0 & 119.0 \\
\hline
\end{tabular}

The total energy (SCF), zero point vibrational energy (ZPVE), rotational constants, specific heat capacity $\left(\mathrm{C}_{\mathrm{v}}\right)$ at constant volume, entropy (S) and dipole moment of adenine are provided in the Table 2.

Table 2. Calculated thermodynamic parameters of adenine

\begin{tabular}{|c|c|c|c|c|c|}
\hline $\begin{array}{c}\text { SCF energy } \\
\text { /Hatree }\end{array}$ & $\begin{array}{c}\text { Z PV energy } \\
/ \mathrm{kcal} \text { mole }^{-1}\end{array}$ & $\begin{array}{c}\text { Rotational } \\
\text { constant } \\
/ \mathrm{GHz}\end{array}$ & $\begin{array}{c}\text { Specific heat } \\
\text { Capacity }(\mathrm{Cv}) \\
/ \mathrm{cal} \mathrm{mol}^{-1} \mathrm{~K}^{-1}\end{array}$ & $\begin{array}{c}\text { Entropy (S) } \\
/ \text { cal mol }^{-1} \mathrm{~K}^{-1}\end{array}$ & $\begin{array}{c}\text { Dipole } \\
\text { moment }, \mu \\
\text { /Debye }\end{array}$ \\
\hline-467.4661 & 69.9800 & $\begin{array}{c}2.3775 \\
1.5639 \\
0.9433\end{array}$ & 28.866 & 84.494 & 3.4109 \\
\hline
\end{tabular}

\section{${ }^{1}$ HNMR spectral analysis}

The NMR spectroscopy is one of the most powerful techniques for the structural analysis of organic compounds. It is well-established that the combined use of experimental NMR spectroscopic technique and computational simulation methods give a powerful gadget to interpret and predict the structure of organic compound, even for the structures of large biomolecules. To get theoretical ${ }^{1} \mathrm{H}$ NMR results of adenine, first the full geometry optimization is carried out with the B3LYP/6-311G+(d,p) in gas phase. After optimization, ${ }^{1} \mathrm{H}$ NMR calculations are calculated by using the gauge-including atomic orbital (GIAO) method. The chemical shifts of the compounds are reported in ppm 
relative to tetramethylsilane (TMS) for ${ }^{1} \mathrm{H}$ NMR spectrum presented in Table 3. The chemical shift of $\mathrm{H}(11), \mathrm{H}(12)$, $\mathrm{H}(13), \mathrm{H}(15)$ and $\mathrm{H}(14)$ protons are observed at 8.42, 8.15, $7.58,5.15$ and $4.74 \mathrm{ppm}$, respectively.

Table 3. Calculated ${ }^{1} \mathrm{H}$ NMR data of adenine

\begin{tabular}{|c|c|c|}
\hline $\begin{array}{c}\text { Protons } \\
\text { with } \\
\text { number }\end{array}$ & $\begin{array}{c}\text { Chemical Shift } \\
\text { (This work) } \\
\text { /ppm }\end{array}$ & $\begin{array}{c}\text { Chemical Shift } \\
\text { (Experimental) } \\
\text { /ppm }\end{array}$ \\
\hline $\mathrm{H}(11)$ & 8.42 & 8.14 \\
\hline $\mathrm{H}(12)$ & 8.15 & 8.11 \\
\hline $\mathrm{H}(13)$ & 7.58 & \\
\hline $\mathrm{H}(15)$ & 5.15 & \\
\hline $\mathrm{H}(14)$ & 4.74 & \\
\hline
\end{tabular}

As we know that electron donating atom increases the shielding and moves the resonance towards lower frequency and electron-withdrawing atom can decrease the shielding and moves the resonance of attached proton towards higher frequency.
We have also found similar results for adenine. As amino protons, $\mathrm{H}(15)$ and $\mathrm{H}(14)$ are de-shielded compared to the other protons, chemical shift moves to the lower frequency region. $\mathrm{H}(15)$ shows chemical shift at $5.15 \mathrm{ppm}$ whereas $\mathrm{H}(14)$ shows at $4.74 \mathrm{ppm}$. This difference in chemical shift is due to the interaction with nearest nitrogen atoms. Theoretically we measured the distance between $\mathrm{H}(15)$ and $\mathrm{N}(7)$ is $2.82 \AA$ and $\mathrm{H}(14)$ and $\mathrm{N}(1)$ is $2.52 \AA$. Experimental ${ }^{1} \mathrm{H}$ NMR spectrum of adenine shows exactly similar results depending upon solvents. ${ }^{20}$

\section{Vibrational spectral analysis}

The assignments of the vibrational frequencies (calculated and observed) are shown in Table 4. In the calculated spectrum of adenine, four IR active mode of vibrations were found at 1542, 3420, 3445 and $3540 \mathrm{~cm}^{-1}$ which are assigned as scissoring vibration of $-\mathrm{NH}_{2}$, symmetric stretching vibration of $-\mathrm{NH}_{2}$, free $-\mathrm{NH}$ vibration and antisymmetric stretching vibration of $-\mathrm{NH}_{2}$ respectively. Three IR absorption bands at 3400, 3441 and $3495 \mathrm{~cm}^{-1}$ were observed experimentally which are assigned assymmetric stretching vibration of $-\mathrm{NH}_{2}$, free $-\mathrm{NH}$ vibration and antisymmetric stretching vibration of $-\mathrm{NH}_{2}$, respectively. ${ }^{21}$

Table 4. IR calculated and experimental frequencies of adenine

\begin{tabular}{|c|c|c|}
\hline $\begin{array}{c}\text { IR calculated } \\
\text { frequencies/cm }\end{array}$ & $\begin{array}{c}\text { IR experimental } \\
\text { frequencies/cm }\end{array}$ & IR active mode of vibration \\
\hline 1542 & - & Scissoring of $-\mathrm{NH} 2$ \\
\hline 3420 & 3400 & Symmetric -NH2 stretching vibration \\
\hline 3445 & 3441 & Free -NH stretching vibration \\
\hline 3540 & 3495 & Anti-symmetric -NH2 stretching vibration \\
\hline
\end{tabular}

Calculated values were corrected by multiplying the frequency factor, $f=0.950$

Table 5. Calculated wavelengths $\lambda(\mathrm{nm})$, excitation energies $\mathrm{E}(\mathrm{eV})$ and oscillator strength (f) and major electronic transitions of adenine

\begin{tabular}{|c|c|c|c|}
\hline$\lambda / \mathrm{nm}$ & $\mathrm{E} / \mathrm{eV}$ & $\mathrm{f}$ & Major transitions \\
\hline 251 & 4.93 & 0.273 & $\mathrm{H} \rightarrow \mathrm{L}(90 \%) \& \mathrm{H} \rightarrow \mathrm{L}+1(4 \%)$ \\
243 & 5.10 & 0.0007 & $\mathrm{H}-1 \rightarrow \mathrm{L}(98 \%)$ \\
\hline \multicolumn{3}{|c|}{$\mathrm{H}=\mathrm{HOMO} \& \mathrm{~L}=\mathrm{LUMO}$} \\
\hline
\end{tabular}

The computed electronic values such as absorption wavelength $(\lambda)$, excitation energies (E) and oscillator strengths (f) are tabulated in Table 5. The major transition with highest oscillator strength for adenine molecule is at $251 \mathrm{~nm}(4.93 \mathrm{eV})$. This transition occurs from HOMO to LUMO $(90 \%)\left(\pi \rightarrow \pi^{*}\right)$ with a minor transition at $243 \mathrm{~nm}$
$(5.10 \mathrm{eV})$ from HOMO-1 to LUMO. Experimental ${ }^{22}$ and theoretical UV-Visible absorption spectrum of adenine is shown in Fig. 2. From the figure it is very clear that adenine is a colorless compound as it does not absorb any visible light.

The experimental UV-Visible absorption spectrum of adenine is at $261 \mathrm{~nm}$ which shows that our calculated spectrum is in very good agreement with experiment. Little red shift from $251 \mathrm{~nm}$ is due to the solvent used to measure UV-Visible absorption spectrum of adenine. As we know that the frontier molecular orbitals (FMO) play an important role in the optical and electronic properties. The highest occupied molecular orbital (HOMO) and the lowest unoccupied molecular orbital (LUMO) energy were calculated by TD-DFT/B3LYP/6-311+G(d,p) method and the HOMO-LUMO energy gap of adenine is as follows: 

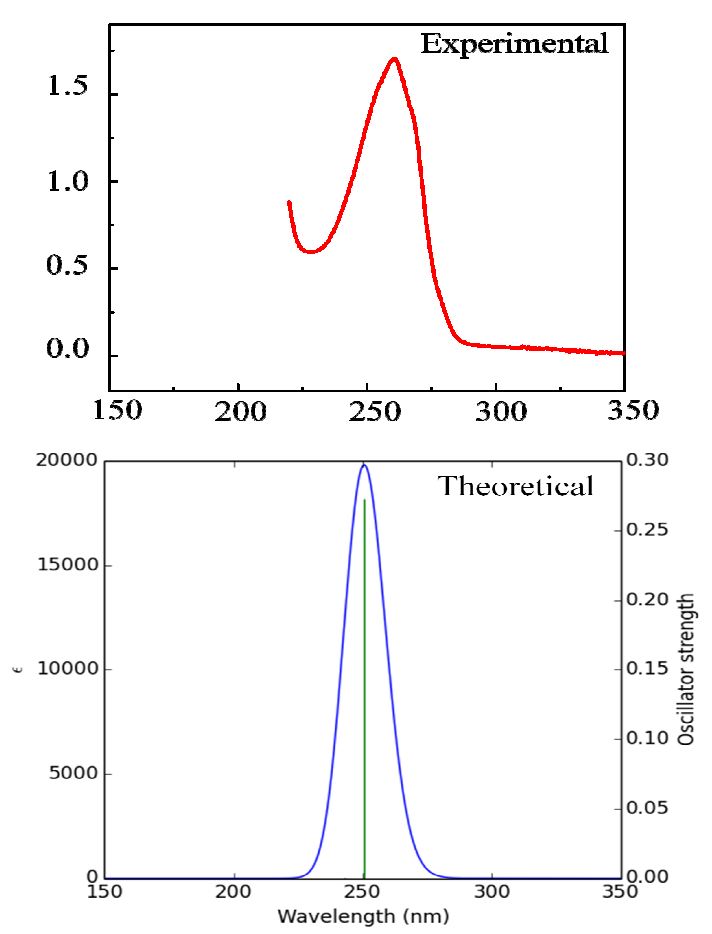

Fig. 2. Experimental (upper panel) and calculated (lower panel) UV-Vis absorption spectrum of adenine

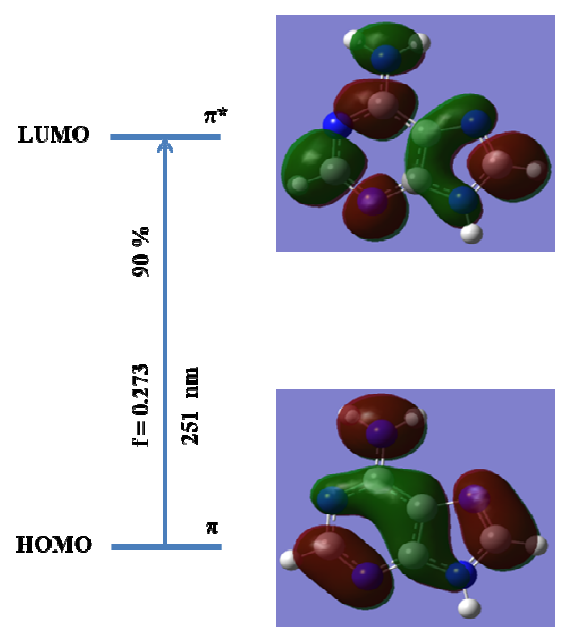

Fig. 3. Jablonski diagram and singlet excited-state transition from $\mathrm{HOMO} \rightarrow$ LUMO of adenine.

$$
\begin{aligned}
& \mathrm{HOMO}_{\text {energy }}(\mathrm{B} 3 \mathrm{LYP})=-6.45 \mathrm{eV}, \\
& \mathrm{LUMO}_{\text {energy }}(\mathrm{B} 3 \mathrm{LYP})=-1.10 \mathrm{eV} \\
& \mathrm{HOMO}-\mathrm{LUMO} \text { energy gap }(\mathrm{B} 3 \mathrm{LYP})=5.35 \mathrm{eV}
\end{aligned}
$$

Therefore the energy gap of FMO of adenine is $5.35 \mathrm{eV}$. The HOMO and LUMO that participate in lowest electronic transitions of adenine are presented in Fig. 3 as a Jablonski diagram.

\section{Conclusion}

The molecular geometry optimization, thermodynamic properties, vibration frequency assignments, electronic and optical properties of adenine molecule were studied theoretically. The optimized geometrical parameters such as bond distances and bond angles are well converged with respect to the experimental values. The calculated ${ }^{1} \mathrm{H}$ NMR chemical shift spectra of the aromatic $\mathrm{C}-\mathrm{H}$ protons range between 8.0 to $8.15 \mathrm{ppm}$ which are in well accord with the experimental data. The calculated IR active mode of vibrations and their assignments are in reasonable agreement with the available experimental data. The investigation of electronic properties shows that the HOMOLUMO energy band gap of adenine at B3LYP level is 5.35 $\mathrm{eV}$. The calculation of optical properties at excited states shows that the major transition (from HOMO to LUMO $\left.(90 \%)\left(\pi \rightarrow \pi^{*}\right)\right)$ occurs at $251 \mathrm{~nm}(4.93 \mathrm{eV})$ with a minor transition at $243 \mathrm{~nm}(5.10 \mathrm{eV})$. Our theoretical UV-Visible absorption spectrum clearly suggests that adenine is a colorless compound as it does not absorb any visible light which is in good agreement with experiment.

\section{Acknowledgement}

This work was supported by Dean Office, Faculty of Science, University of Dhaka, Dhaka-1000, Bangladesh.

\section{References}

1. Szyc L., M. Yang, E. T. J. Nibbering, T. Elsaesser, 2010. Ultrafast Vibrational Dynamics and Local Interactions of Hydrated DNA. Angew. Chem. Int. Ed. 49, 3598-3610.

2. Samoylova E., H. Lippert, S. Ullrich, I. V. Hertel, W. Radloff, T. Schultz, 2005. Dynamics of Photoinduced Processes in Adenine and Thymine Base Pairs, J. Am. Chem. Soc.127,17821786.

3. Canuel C., M. Mons, F. Piuzzi, B. Tardivel, I. Dimicoli, 2005. Excited states dynamics of DNA and RNA bases: Characterization of astepwise deactivation pathway in the gas phase. J. Chem. Phys.122, 074316-6.

4. Pecourt J. M. L., J. Peon, B. Kohler, 2001. DNA Excited-State Dynamics: Ultrafast Internal Conversion and Vibrational Cooling in a Series of Nucleosides. J. Am. Chem. Soc. 123 (42), 13070-10378.

5. Kang H., K. T. Lee, B. Jung, Y. J. ko, S. K. Kim, 2002. Intrinsic Lifetimes of the Excited State of DNA and RNA Bases. J. Am. Chem. Soc.124, 12958-12959.

6. Gustavsson T., R. Improta, D. Markovitsi, 2010. DNA/RNA: Building Blocks of Life Under UV Irradiation. J. Phys. Chem. Lett.1, 2025-2030.

7. Ullrich S., T. Schultz, M. Z. Zgierski, A. Stolow, 2004. Direct Observation of Electronic Relaxation Dynamics in Adenine via Time-Resolved Photoelectron Spectroscopy. J. Am.Chem. Soc. 126, 2262-2263.

8. Ho J. W., H. C. Yen, W. K. Chou, C. N. Weng, L. H. Cheng, H. Q. Shi, S. H. Lai, P. Y. Cheng, 2011. Disentangling Intrinsic Ultrafast Excited-State Dynamics of Cytosine Tautomers.

J. Phys. Chem. A 115, 8406-8418.

9. Kwok W. M., C. Ma, D. L. Phillips, 2008. A Doorway State Leads to Photostability or Triplet Photodamage in Thymine DNA. J. Am. Chem. Soc.130, 5131-5139.

10. Lange A. W., J. M. Herbert, 2009. Both Intra- and Interstrand Charge-Transfer Excited States in Aqueous B-DNA Are 
Present at Energies Comparable To, or Just Above, the ${ }^{1} \pi \pi^{*}$ Excitonic Bright States. J. Am. Chem. Soc. 131, 3913-3922.

11. Kang H., B. Jung, S. K. Kim, 2003. Mechanism for ultrafast internal conversion of adenine. J. Chem. Phys. 118, 6717-6719.

12. Kohler B., 2010. Nonradiative Decay Mechanisms in DNA Model Systems. J. Phys. Chem. Lett. 1, 2047-2053.

13. Middleton C. T., K. D. L. Harpe, C. Su, Y. K. Law, C. E. C. Hernandez, B. Kohler, 2009. DNA Excited-State Dynamics: From Single Bases to the Double Helix, Annu. Rev. Phys. Chem. 60, 217-39.

14. Ghane T., G. Brancolini, D. Varsano, R. D. Felice, 2012. Optical Properties of Triplex DNA from Time-Dependent Density Functional Theory, J. Phys. Chem. B 116, 1069310702.

15. Varsano D., R. D. Felice, M. A. L. Marques, A. Rubio, 2006. A TD-DFT Study of the Excited States of DNA Bases and Their Assemblies. J. Phys. Chem. B 110, 7129-7138.

16. Sobolewski A. L., W. Domcke, 2002. On the mechanism of nonradiative decay of DNA bases: ab initio and TD-DFT results for the excited states of $9 \mathrm{H}$-adenine. Eur. Phys. J. D. 20, 369-374.

17. Becke A. D., 1993. Density-functional thermochemistry. III. The role of exact exchange. J. Chem. Phys. 98, 5648-5652.

18. Frisch M. J., G.W. Trucks, H. B. Schlegel, G.E. Scuseria, M.A. Robb, J.R. Cheeseman,G. Scalmani, V. Barone, B. Mennucci, G.A. Petersson, H. Nakatsuji, M. Caricato,X. Li, H.P. Hratchian, A.F. Izmaylov, J. Bloino, G. Zheng, J.L. Sonnenberg, M.Hada, M. Ehara, K. Toyota, R. Fukuda, J. Hasegawa, M. Ishida, T. Nakajima, Y.Honda, O. Kitao, H.
Nakai, T. Vreven, J.A. Montgomery Jr., J.E. Peralta, F. Ogliaro,M. Bearpark, J.J. Heyd, E. Brothers, K.N. Kudin, V.N. Staroverov, R. Kobayashi, J.Normand, K. Raghavachari, A. Rendell, J.C. Burant, S.S. Iyengar, J. Tomasi, M.Cossi, N. Rega, N.J. Millam, M. Klene, J.E. Knox, J.B. Cross, V. Bakken, C. Adamo, J.Jaramillo, R. Gomperts, R.E. Stratmann, O. Yazyev, A.J. Austin, R. Cammi, C.Pomelli, J.W. Ochterski, R. L. Martin, K. Morokuma, V.G. Zakrzewski, G.A. Voth,P. Salvador, J.J. Dannenberg, S. Dapprich, A.D. Daniels, O. Farkas, J.B. Foresman,J.V. Ortiz, J. Cioslowski, D.J Fox, Gaussian, Inc., Wallingford CT, 2009.

19. Taylor R., 0. Kennard, 1982. The molecular structures of nucleosides and nucleotides: Part 1 . The influence of protonation on the geometries of nucleic acid constituents. $J$. Mol. Struct. 78(1), 1-28.

20. Human Metabolome Data Base (HMDB0034)/1H NMR spectrum of adenine: $500 \mathrm{MHz}$ in $\mathrm{H}_{2} \mathrm{O}$. (http://www.hmdb.ca/metabolites/HMDB00034).

21. Alauddin M., M. Roy, J. K. Song, S. M. Park, 2015. Infrared photodissociation of adenine $\operatorname{dimer}\left(\mathrm{H}_{2} \mathrm{O}\right) \mathrm{n}^{+}(\mathrm{n}=1-4)$ clusters, Intl. J. Mass Spectrom. 381, 41-47.

22. PhotochemCad/MolecularDatabase/Adenine Absorption. 
Dhaka Univ. J. Sci. 64(1): 77-81, 2016 (January) 